\title{
The role of an in-house audit group as an innovative tool to review clinical trials
}

\author{
Shivali Trivedi, Krishna Hathi, Natasha Aslam, Nausheen Saleem, Kylie Gyertson, Jeremy Whelan \\ From 3rd International Clinical Trials Methodology Conference \\ Glasgow, UK. 16-17 November 2015
}

\section{Background}

Auditing is an integral part of quality assurance in trials. The introduction of risk-based monitoring in industry coupled with reduced funding for academic trials indicates a need to enhance the comprehensive oversight of trials. Generating an internal audit system streamlines quality management across the clinical trials unit. We aimed to pilot a robust in-house process that prioritises patient safety and monitors trial delivery.

\section{Methods}

Ten healthcare professionals within our team voluntarily formed an internal audit group and received appropriate training. Sub-teams were assigned individual trials to audit over a three month period. Quality and SOP compliance data was collated in a comprehensive audit spreadsheet and processes covered included examination of Site Files, Case Report Forms, Serious Adverse Events (SAE), and source data verification (SDV). Findings were amalgamated into a Corrective Action Preventative Action (CAPA) Plan and fed back to the wider team. Team actions were subsequently reviewed after six weeks as a follow-up measure.

\section{Results}

Preliminary findings of five internal audits highlighted areas for improvement within data and procedural systems including; informed consent, SAE reporting, and SDV. Additionally, the Audit Group proved a useful measure in developing overall quality standards of the team, highlighted by staff learning, improved knowledge and adherence to regulatory standards.

\section{Conclusions}

In line with upcoming EU legislation and ICH GCP, maintaining rigorous auditing processes and adherence to

University College London Hospitals, London, UK quality standards is of utmost importance. The ongoing quarterly internal audit cycle will be continuously reviewed, feeding into an evolving quality management system ensuring best practice across the unit.

Published: 16 November 2015

doi:10.1186/1745-6215-16-S2-050

Cite this article as: Trivedi et al:: The role of an in-house audit group as an innovative tool to review clinical trials. Trials 2015 16(Suppl 2):O50.
Submit your next manuscript to BioMed Central and take full advantage of:

- Convenient online submission

- Thorough peer review

- No space constraints or color figure charges

- Immediate publication on acceptance

- Inclusion in PubMed, CAS, Scopus and Google Scholar

- Research which is freely available for redistribution
() Biomed Central 